\title{
Thinking Like a Lawyer
}

\author{
Klaas Rozemond
}

F. Schauer, Thinking Like a Lawyer, Cambridge, Mass.: Harvard University Press 2009

Juridisch redeneren is het toepassen van regels en precedenten op feiten. Frederick Schauer wil deze manier van redeneren uitleggen in zijn boek Thinking Like a Lawyer. Volgens Schauer is een kenmerkend aspect van juridisch denken het suboptimale karakter ervan. Iemand die een regel toepast of een precedent volgt, doet iets anders dan het nemen van een beslissing die de beste resultaten oplevert in een bepaald geval. De regeltoepasser en de precedentvolger zien af van het beste resultaat vanwege de autoriteit van degene die de regel of het precedent heeft opgesteld. Juridisch redeneren is het gehoorzamen van die autoriteit en daarmee zijn de belangrijkste aspecten (suboptimaliteit en autoriteit) van juridisch redeneren volgens Schauer gegeven.

De regeltoepasser heeft volgens Schauer in beginsel niet de bevoegdheid om zelfstandig te onderzoeken of het belang dat aan de regel ten grondslag ligt daadwerkelijk wordt beschermd door de regeltoepassing. Hij moet de regel toepassen, ook al blijkt niet dat het beschermde belang daarmee in het betreffende geval is gediend, bijvoorbeeld bij de toepassing van een snelheidsregel in het verkeer. Het verweer van de overtreder dat hij weliswaar $140 \mathrm{~km} / \mathrm{u}$ reed op een weg waar slechts $120 \mathrm{~km} / \mathrm{u}$ is toegestaan, maar dat hij dat op een nachtelijk tijdstip deed terwijl er geen overig verkeer op de weg aanwezig was, is geen relevant verweer met betrekking tot de rechtsvraag of de regel van toepassing is: de regel geeft duidelijk aan dat de betrokkene te hard reed en daarom een strafbaar feit pleegde.

Schauer noemt dit het formele aspect van het recht. Hij geeft toe dat dit aspect in bepaalde gevallen ter discussie kan worden gesteld, vooral wanneer de uitkomst van regeltoepassing extreem onrechtvaardig lijkt te zijn. Toch kan volgens Schauer het formalistische uitgangspunt niet worden veronachtzaamd, omdat het de essentie van juridische redeneren is ter onderscheiding van andere vormen van denken. Er kan alleen sprake zijn van bindende regels en precedenten wanneer de toepasser of de volger ervan zijn of haar eigen oordeel over de wenselijke uitkomst in beginsel terzijde schuift vanwege de autoriteit van het precedent. In verband met precedenten geldt dit in ieder geval ten aanzien van beslissingen van hogere rechters, maar niet zonder meer ten aanzien van eigen eerdere beslissingen. Voor deze laatste categorie geldt volgens Schauer echter wel het argument van stabiliteit: de rechter is gebonden aan zijn eigen beslissingen in het belang van de stabiliteit van het recht. Opmerkelijk hierbij is dat het stabiliteitsargument

* Mr. dr. Klaas Rozemond is universitair hoofddocent strafrecht aan de Vrije Universiteit Amsterdam. 
geen autoriteitsargument is, maar een argument met betrekking tot de wenselijke resultaten van rechterlijke beslissingen. Schauer gaat aan dit punt voorbij, maar dit gegeven lijkt wel afbreuk te doen aan zijn formalistische autoriteitstheorie.

Het volgen van een autoriteit is volgens Schauer inhoudsonafhankelijk. De beslissing van een autoriteit wordt niet gevolgd vanwege de inhoudelijke redenen die aan de beslissing ten grondslag liggen, maar vanwege het gegeven dat een autoriteit de beslissing heeft genomen, waardoor de beslissing bindend wordt voor de personen en instanties die aan deze autoriteit zijn onderworpen. Waarom bepaalde instanties als juridische autoriteiten worden aangemerkt die bindende beslissingen kunnen nemen, is volgens Schauer in navolging van Hart uiteindelijk een kwestie van een veranderlijke sociale praktijk. Het bindende karakter van beslissingen vanwege de autoriteit van degene die de beslissing neemt, verklaart volgens Schauer de suboptimale uitkomst van regeltoepassing en precedentvolging.

De kern van juridisch redeneren zou kunnen worden samengevat als een verbod om een eigen oordeel te vormen over het wenselijke resultaat in een bepaald geval. Deze typering van juridische redeneren roept allereerst de vraag op of het recht inderdaad een dergelijke autoritaire kern heeft. Deze opvatting wordt betwist door rechtsrealisten die betogen dat rechters juist wel beslissen met het oog op wenselijke resultaten en dat zij zich daarbij niet gebonden achten aan regels en precedenten of sterker nog: regels en precedenten bevatten altijd een mogelijke rechtvaardiging voor tegenovergestelde beslissingen in een bepaald geval en daaruit volgt dat de rechter zijn beslissing wel moet nemen op basis van buitenjuridische maatstaven over wenselijke resultaten. De beslissing kan altijd achteraf worden gerechtvaardigd met behulp van juridische maatstaven die argumenten voor de beslissing opleveren.

Als algemene theorie over het recht is het realisme volgens Schauer niet plausibel en hij wijst erop dat Karl Llewellyn zijn realistische theorie alleen van toepassing achtte in moeilijke gevallen waarin partijen onderling van mening verschillen over de juiste uitkomst. Dergelijke gevallen zijn aanleiding voor rechterlijke procedures en niet de eenvoudige gevallen waarin de uitkomst van een procedure bij voorbaat vaststaat. In moeilijke gevallen is volgens de realisten de ideologie van de rechter bepalend voor de uitkomst van zijn beslissing. Volgens Schauer heeft deze typering van de rechterlijke beslissing in moeilijke gevallen slechts een beperkte gelding. Waarschijnlijk gaat de typering op voor hoogste rechters (bijvoorbeeld het Amerikaanse Supreme Court waarnaar empirisch onderzoek is gedaan met een dergelijke uitkomst), maar niet voor lagere rechters die zich volgens Schauer in veel sterkere mate laten leiden door regels en precedenten. Volgens Schauer zou hiernaar empirisch onderzoek kunnen worden gedaan, waarbij hij de voorspelling doet dat lagere rechters gezagsgetrouwer zijn dan de realisten veronderstellen. Kern van Schauers positie is ook hier dat het bindende karakter van eerdere beslissingen kenmerkend is voor het recht, wat niet wegneemt dat rechters in een beperkt aantal moeilijke gevallen beslissingen moeten noemen waarmee een precedent wordt geschapen in plaats van gevolgd. 
Schauers formalisme is bepalend voor de wijze waarop hij kwesties bespreekt als het verschil tussen analogie en precedent, de interpretatie van wettelijke regels en de vaststelling van de feiten in rechterlijke procedures. Daardoor kan de lezer van zijn boek het gevoel krijgen dat Schauer een belangrijk kenmerk van het juridische denken heeft gemist. Schauer geeft in zijn boek geen antwoord op de vraag waarop de autoriteit van juridische instanties als de wetgever en de rechter berust. Er ontbreekt daardoor een theoretisch fundament voor Schauers formalisme. Hij zou van oordeel kunnen zijn dat een dergelijk fundament buiten het juridische denken valt, zodat hij er in zijn boek niet op in hoeft te gaan. Het zou echter ook zo kunnen zijn dat het theoretische fundament van juridische autoriteit mede bepalend is voor de wijze waarop regels en precedenten bindend zijn en moeten worden uitgelegd en toegepast.

Een alternatieve opvatting zou de theorie kunnen zijn dat het uiteindelijke fundament van het recht niet inhoudsonafhankelijk is, zoals Schauer met zijn formalisme betoogt, maar dat het fundament van het recht bestaat uit basisnormen die niet te herleiden zijn tot bindende beslissingen van juridische autoriteiten. In een democratische samenleving is de autoriteit van wettelijke regels gebaseerd op de democratische procedure waarin die regels tot stand zijn gekomen en de democratische legitimatie van deze procedure is gefundeerd op een normatieve opvatting over de gelijkwaardigheid van personen en de grondrechten waarin deze gelijkwaardigheid tot uitdrukking komt. Het is mogelijk dat een dergelijke basis is neergelegd in formele teksten met juridische autoriteit zoals een grondwet, maar de legitimatie van dergelijke formele teksten berust uiteindelijk op een normatieve theorie over de gelijkwaardigheid van personen. De betekenis van regels, precedenten en grondrechten wordt mede door de inhoud van zo'n normatieve theorie bepaald, en het juridische gezag van wetten en precedenten berust voor een belangrijk deel op de mate waarin dergelijke beslissingen met behulp van inhoudelijke argumenten kunnen worden gerechtvaardigd. Ook de vraag of een bepaald geval eenvoudig of moeilijk is, wordt mede bepaald door het antwoord op de vraag in hoeverre bepaalde regels of precedenten in overeenstemming zijn met fundamentele basisnormen waaraan het recht zijn legitimatie ontleent.

De lezer die een dergelijke alternatieve theorie niet zonder meer ongeloofwaardig acht, kan een onbevredigd gevoel overhouden aan de lezing van Schauers boek. Schauer lijkt te veronderstellen dat het antwoord op de vraag wat het fundament van juridische autoriteit is niet relevant is voor het antwoord op de vragen waarom regels en precedenten bindend zijn en waarom rechters in beginsel niet bevoegd zijn om een eigen oordeel te geven over de wenselijkheid van een bepaalde beslissing. Het is natuurlijk niet uitgesloten dat eigen oordeelsvorming door de rechter inderdaad zoveel mogelijk moet worden uitgesloten in het licht van de normatieve fundamenten van het recht (democratische legitimatie, gelijkwaardigheid van personen), maar dat had Schauer dan moeten beargumenteren. Rechterlijke terughoudendheid is voor juristen niet zonder meer een gegeven, maar die terughoudendheid zou wel uit een inhoudelijke argumentatie over de grondslagen van het recht kunnen worden afgeleid en dat zou betekenen dat het 
idee van juridische autoriteit niet alleen op die autoriteit zelf kan zijn gebaseerd, maar op inhoudelijke argumenten moet berusten. Ook juristen moeten nadenken over de vraag waarom zij in bepaalde gevallen geen eigen oordeel over de wenselijkheid van een beslissing mogen geven. In een boek over het denken van juristen moet daarom ook aandacht worden besteed aan de vraag wat de fundamenten van het recht zijn. Het is mogelijk dat het antwoord op die vraag uitmondt in Schauers formalisme, maar dat antwoord kan niet zonder nadere argumentatie als juist worden verondersteld, zeker niet door een jurist die wil nadenken over de vraag waarom de beslissing van een bepaalde autoriteit bindend is.

Een gemis in het boek is ook dat Schauer niet heel uitgebreid ingaat op de rechtsvormende activiteiten van de rechter. Een kenmerk van moderne rechtsstelsels is dat rechtspraak een zelfstandige rechtsbron is naast wetgeving en dat kenmerk kan niet zonder meer worden verklaard aan de hand van Schauers formalisme, zoals bijvoorbeeld blijkt uit het hiervoor gesignaleerde probleem van binding van een rechter aan zijn eigen beslissingen. Deze binding berust niet op een autoriteitsargument, maar op een resultaatsargument met betrekking tot de vereiste stabiliteit van het recht. Ook in zijn bespreking van de common law besteedt Schauer relatief weinig aandacht aan de rechtsvormende activiteiten van de rechter; hij benadrukt hij vooral het bindende karakter van precedenten, waarbij hij waarschuwt voor te snelle veranderingen in de common law en een restrictieve toepassing bepleit van de billijkheid als corrigerende factor in een rechtssysteem. Schauer erkent de noodzaak van een bepaalde mate van flexibiliteit bij evident onrechtvaardige uitkomsten. Zijn uitgangspunt blijft echter het beginsel dat de rechter niet bevoegd is om de resultaten van beslissingen te optimaliseren aan de hand van buitenjuridische maatstaven, waarbij het argument van stabiliteit belangrijker lijkt te zijn dan het argument van autoriteit.

De vraag in hoeverre rechters in het belang van de stabiliteit van het recht terughoudend moeten zijn bij de rechterlijke rechtsvorming zou echter afhankelijk kunnen worden gesteld van een analyse van de rechterlijke rechtsvorming in moderne rechtstelsels. Bij een dergelijke analyse staat niet bij voorbaat vast dat het recht op onaanvaardbare wijze zijn stabiliteit verliest wanneer de bindende werking van regels en precedenten wordt afgezwakt. Of dat het geval is, hangt af van een analyse van de effecten van rechterlijke rechtsvorming en die analyse ontbreekt in Schauers boek. Het zou juist een kenmerkend aspect van het recht van een democratische samenleving kunnen zijn dat mensen minder autoriteitsgevoelig zijn en meer behoefte hebben aan inhoudsafhankelijk recht waarbij het gezag van de beslissing niet afhangt van de autoriteit van de rechter of de wetgever, maar van de inhoud van de argumenten die voor wetgeving en rechtspraak worden aangevoerd. De alternatieve hypothese zou zijn dat het recht in een moderne samenleving flexibeler en inhoudelijker zou moeten zijn dan Schauer met zijn formalisme toelaatbaar acht en dat het verlies aan stabiliteit minder belangrijk is dan hij veronderstelt. Je zou van iedere jurist mogen verwachten dat hij of zij in staat is om over een dergelijk alternatief na te denken en ook in staat is om een beargumenteerde keuze te maken tussen verschillende benaderingen 
van het recht. Schauer had daarom in zijn Thinking Like a Lawyer meer aandacht moeten besteden aan de inhoudelijke eisen die aan het recht kunnen worden gesteld voordat het als bindend recht kan worden aangemerkt. 